\title{
Post-eruption Plant Recovery with Reference to Geomorphic Processes in the Summit Atrio of Mt. Usu, Japan
}

\author{
Tamio CHINEN* and Anne Riviere**
}

\begin{abstract}
In the atrio of Mt. Usu, Hokkaido, Japan which was severely devastated by the 1977 - 1978 eruptions, we examined natural plant recovery and erosional and depositional patterns during the period $1977-1984$ on the basis of field examination and aerial photo interpretation. Plant recovery processes, survival and invasion (disseminule origin), dynamically interacted with geomorphic processes. The strategy of survival contributed to a great extent to plant recovery. Tree basal remnants and buried branches sent new shoots in zones of lesser burial. Underground storage organs of numerous herbaceous plants easily perforated thicker deposits than the woody plants and therefore survived in a wider area. Survival and invasion of herbaceous plants in erosional rills and gullies were a common feature of hillslopes that were thickly covered with tephra. Pioneer trees issued from light anemochorous seeds first invaded rapidly inactivated alluvial fans which were characteristically covered with ash and pumice. Herbaceous plants also invaded preferentially on the pumiceous substratum than on the ash field. Rilling and gullying, though sometimes destructive, played an important role in transporting organic debris and seeds with hard coats from upper somma walls to lower slopes and alluvial fans. Plants (pioneer trees and herbs) established on alluvial fans were largely dependent on inactivation of geomorphic processes. Surface erosion rate had already declined before the plants had started to recover, implying little protective role of plant recovery on erosion; deceleration of geomorphic activity had a positive influence on plant recovery. In summary, plant recovery largely depended on combined effects of direct eruptive damage, especially tephra thickness, and post-eruption erosion and deposition processes.
\end{abstract}

\section{INTRODUCTION}

Volcanic eruptions undoubtedly affect landscape development in volcanic regions by disturbing pre-existing erosional and vegetational patterns. The volcanic history of Mt. Usu as described below and other volcanoes in Japan suggest that volcanic perturbations happen at ecologically relevant time scales. The $1977-1978$ eruptions of Mt. Usu were characterized by huge quantities of ejecta and remarkable land deformation, and caused severe damages to the natural and artificial forests which were covering the volcano slopes. The summit caldera, which had been covered with a natural broad-leaved forest, was the most damaged area but offered the rare opportunity of examining recovery processes of the vegetation in response to various kinds of damages such as thick tephra accumulation and severe erosion, etc. We have monitored the posteruption surface erosion and plant recovery at the atrio (Riviere, 1982, 1984, 1986; CHINEN, 1986, in press; CHINEN and KADOMURA, 1984, 1986; Riviere and Kadomura, 1984; CHINEN and RIVIERE, in press).

A number of studies of erosion processes after the 1977-1978 eruptions of Mt. Usu have been undertaken (e.g., KADOMURA et al., 1978; YАMАMOTO et al., 1980; YAMAGISHI et al., 1982;

*Laboratoire de la Montagne Alpine, Institut de Géographie Alpine, Université de Grenoble I, Rue Maurice Gignoux, 38031 Grenoble Cedex, France

**34, Rue Lenoir, 72000 Le Mans, France 
KADOMURA et al., 1983; ImAgawa, 1984; YAMAMOTO, 1984). However, most studies have been centered on debris and mud flow occurrences and slope erosion on the outer somma slopes and valleys; few studies of surface erosion have been carried out at the atrio. On the other hand, several vegetation studies were conducted after the 1977-1978 eruptions (ITO, 1978; Higashi, 1980; TAKAHATA, 1980; Ito and HaRUKI, 1980, 1984; Ito and Shimizu, 1980; YANAI, 1981; OKAMURA, 1985). As the relation between revegetation and erosion processes has been dynamic, plant recovery is best Understood in terms of linkage of both processes.

Studies of post-eruption plant recovery and its linkage with erosion have been reported from Kodiak and Katmai in USA (GrigGS, 1918, 1919, 1933), Parícutin in Mexico (EGGLER, 1948; Segerstrom, 1950, 1960, 1961, 1966), Tarawera in New Zealand (Burke, 1964), Irazú in Costa Rica (WALdron, 1967), Mt. Vulcan in New Guinea (Ollier and Brown, 1971), Mt. Usu (Kadomura et al., 1978, etc.), Mt. Sakurajima in Japan (Shimokawa and TANiguchi, 1983; Shimokawa and Jitousono, 1987), Fernandina in Galápagos (Hendrix, 1981), and Mount St. Helens in the USA (Collins et al., 1983; Del Moral, 1983; Lehre et al., 1983; SwANSON et al., 1983; Franklin et al., 1985; Collins and DunNe, 1986, 1988). Uhe (1971) presented a thorough and world-wide review on the pioneer vegetation invading on various recent tephra fields. Diversity of volcanic events and impacts, however, requires that studies of plant recovery should be based on an understanding of indigenous volcanic activities, tephra deposits, and subsequent geomorphic processes.

The present study, based on aerial photo interpretation and field examination during 1980-1984, aims to discuss trends of plant recovery with regard to the initial damage and subsequent erosional and depositional patterns. Dominant erosion processes at the atrio were slope wash, rilling, gullying and small-scale debris flow (CHINEN and Kadomura, 1986). The linkage between revegetation and gullying on slopes has been briefly outlined before (CHINEN and Riviere, in press). Focuses in this paper, therefore, are on general spatio-temporal trends of plant recovery and erosion at the entire atrio.
The effects of sowing of seeds and manmade construction such as terraces, roads, consolidation dams (RIVIERE and KADOMURA, 1984) are excluded in this paper. The erosion control works at the atrio have been conducted since 1981 .

\section{STUDY AREA: MT. USU}

\section{1. $1977-1982$ volcanism}

Mt. Usu $\left(42^{\circ} 32^{\prime} \mathrm{N}, 140^{\circ} 50^{\prime} \mathrm{E}\right)$ is a stratovolcano located in the southwestern part of Hokkaido. Historical eruptions before the 1977-1978 eruptions are known to have occurred in 1663,1769, 1822, 1853, 1910 and 1943-1945 (Yoxoyama et al., 1973). The historical eruptions were either pumice eruptions or phreatomagmatic ones, sometimes accompanied by pyroclastic flows, base surges or volcanic mudflows. Before the $1977-1978$ eruptions, the atrio was topographically characterized by two lava domes, 0-Usu and Ko-Usu (Fig. 1, Photo 1).

The 1977-1978 eruptions occurred in the atrio. As volcanic activities of the eruptions have been already reported (e.g., KATsui et al., 1978; NiIdA et al., 1980; YокочAмA et al., 1981), we briefly refer to some aspects of the activities restricted to the atrio.

The First Stage eruptions, which took place from 7-14 August 1977, produced huge quantities of airfall tephra (NIIDA et al., 1980, 1982). The ejecta, consisting of dacite pumice, ashes and lithic fragments, were thickly deposited around the craters (Fig. 1). The Second Stage eruptions, which occurred intermittently from November 1977 to October 1978, produced ejecta mainly composed of ashes and chiefly accumulated in the south atrio. A number of volcanic blocks and bombs of dacite were also deposited in the atrio. The new tephra reached more than $4 \mathrm{~m}$ deep in the vicinity of the craters, but only $20-30 \mathrm{~cm}$ of tephra accumulated on the northeastern somma rim. The pumice-ash eruptions were followed by notable land deformation. The intrusion of magma beneath the atrio invited a spectacular upheaval and northeastward thrust of a U-shaped block around the main peak of 0-Usu (Photo 1). The crustal deformation ended in March 1982 (U.V.O., 1982). 


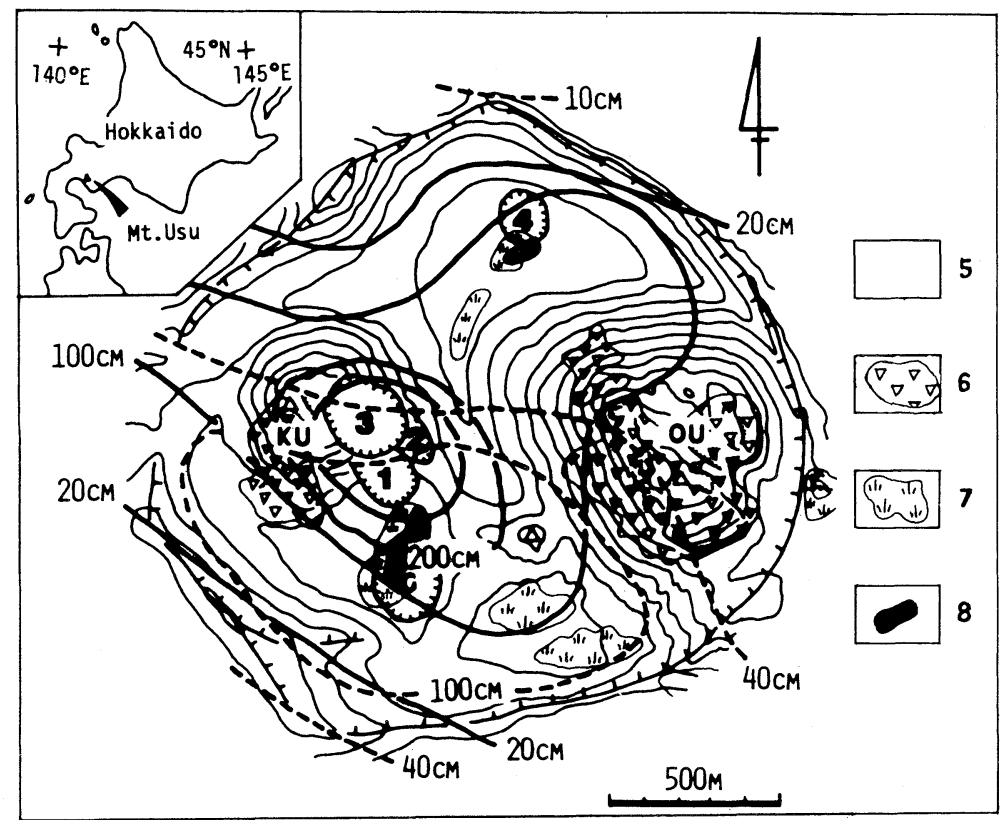

Fig. 1 Map showing isopachs of the new deposited tephra of the 1977-1978 eruptions in the atrio of Mt. Usu (partly modified from KATSUI et al., 1978; NiIDA et al., 1980) and vegetation before the eruptions (modified from ITO and SHIMIZU, 1980) Solid and dashed lines indicate the isopach of the First Stage and Second Stage tephra, respectively. Topographic contours in every $25 \mathrm{~m}$ as of before the eruptions. Numbers $1-4$ and G (Ginnuma) denote craters opened during the eruptions. $5-8$ are legends of pre-eruption vegetation interpreted from the aerial photos taken in September and October 1976. 5: Forest dominated by trees with anemochorous seeds such as poplars, birches and alders; 6: Denuded rocky slope; 7 : Pasture grasses; 8: Pond.

OU: O-Usu (727 m); KU: Ko-Usu (609 m)

Table 1 Monthly and annual mean air temperature $\left({ }^{\circ} \mathrm{C}\right)$, precipitation $(\mathrm{mm})$ and maximum snow depth $(\mathrm{cm})$ at Date City, $8 \mathrm{~km}$ southeast of $\mathrm{Mt}$. Usu

\begin{tabular}{lccccccccccccc}
\hline & Jan. & Feb. & Mar. & Apr. & May & Jun. & Jul. & Aug. & Sep. & Oct. & Nov. & Dec. & Annual \\
\hline Temperature & -3.8 & -3.8 & 0.7 & 5.9 & 10.8 & 14.8 & 19.2 & 20.5 & 17.0 & 11.0 & 4.4 & -1.1 & 8.0 \\
Precipitation & 56 & 67 & 54 & 90 & 82 & 78 & 110 & 143 & 125 & 96 & 82 & 49 & 1030 \\
Snow depth & 57 & 82 & 80 & 46 & 0 & 0 & 0 & 0 & 0 & 5 & 24 & 37 & \\
\hline
\end{tabular}

Record period; $1954-1980$ for temperature, $1952-1980$ for precipitation, and 1917-1980 for snow depth. Data based on J.W.A.(1982)

\subsection{Climate and hydrology}

The climate of this region is humid coldtemperate with a mean precipitation of $1,030 \mathrm{~mm}$ during the last 29 years (Table 1). There is no marked rainy season as in the southern regions of Japan, but rain days tend to be concentrated in three months, from July to September. Snow covers the atrio except for fumarolic zones for five months, from mid-November to mid-April. The maximum snow depth sometimes exceeds
$1.5 \mathrm{~m}$. The monthly average temperatures in $\mathrm{Au}-$ gust and in January are $21^{\circ} \mathrm{C}$ and $-4^{\circ} \mathrm{C}$, respectively (J.W.A., 1982). Less snow cover generally favors soil freezing with a maximum frozen depth of $40 \mathrm{~cm}$ (KINOSHITA and FuKUDA, 1982). However, deep snow cover in winter as mentioned above protects the soil from freezing. Our field observations indicate that frequent freezing and thawing takes place in the upper tephra layer of several centimeters in pre- and postwinter periods. 


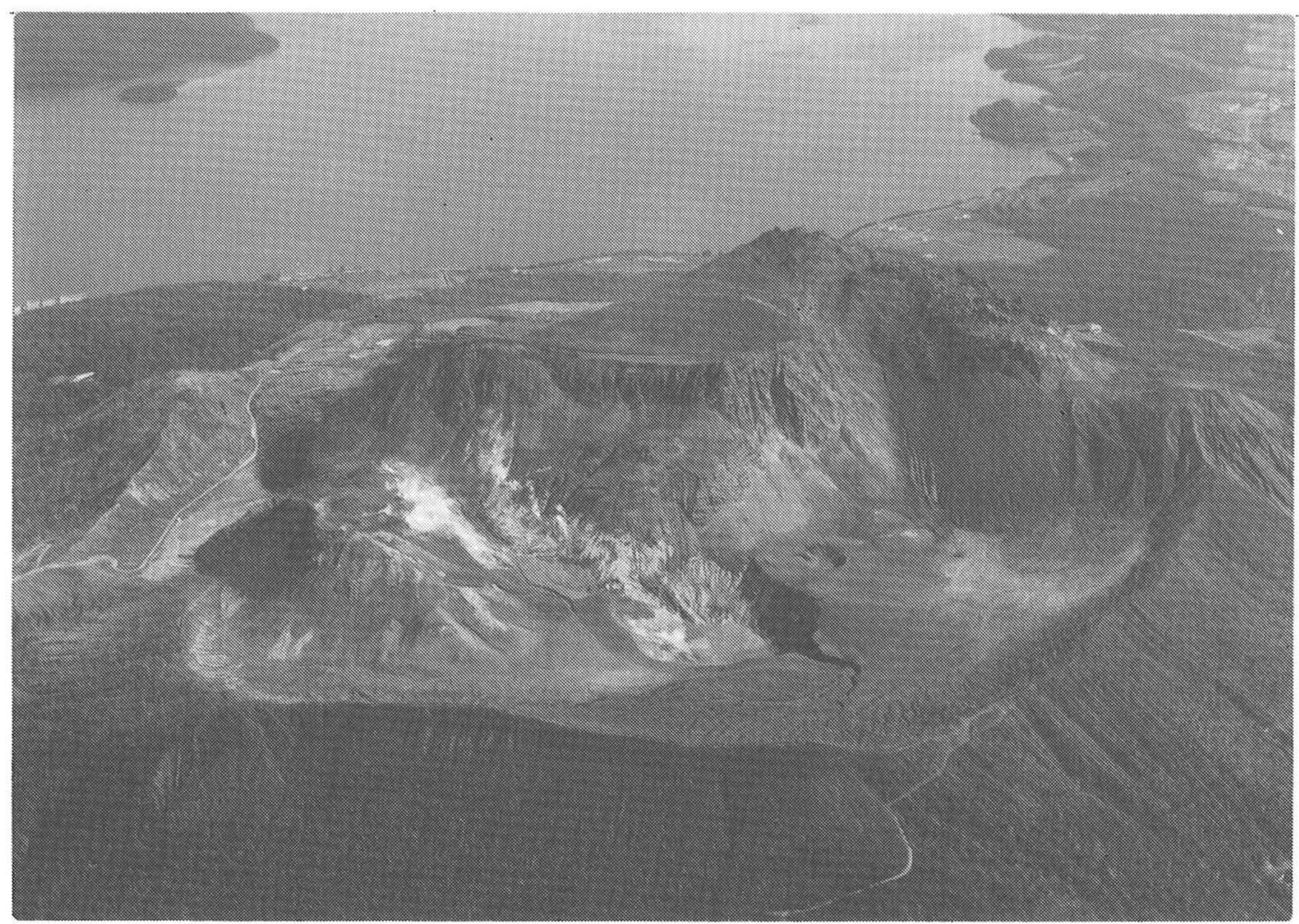

Photo 1 The atrio of Mt. Usu viewed from the southwest, as of August 1982 (taken by Kokusai Aerial Survey Co., Ltd.)

The highest rugged peak is O-Usu. A large fault-scarp which had been associated with "Ogari-yama - Usu Shinzan rise" is in the center. Toya Caldera Lake in the background.

Surface runoff rarely occurs except in the rainy seasons and occasionally in the snowmelt seasons. We observed several occurrences of surface runoff in the atrio. Thus water erosion takes place with intense rainfall in the summer and rapid snowmelting in the spring, and topographic depressions are flooded. The occurrences of surface runoff and associated surface wash and rilling were relatively frequent soon after the accumulation of new tephra (Y АMAмоTо and IMAGAWA, 1983; Yамамото, 1984), because the upper horizon of the new tephra is composed of fine ash and became impermeable as a result of crusting (Kadomura et al., 1978). There is no perennial stream in the atrio.

\subsection{Vegetation}

The natural forest of this region belongs to the cool-temperate deciduous broad-leaved type. Prior to the $1977-1978$ eruptions, forests of Mt.
Usu (Fig. 1) were mostly composed of poplar, Populus maximowiczii; birches, Betula ermanii and B. platyphylla var. japonica and alder, Alnus maximowiczii. Other trees such as Ulmus davidiana var. japonica, Acer mono, Fraxinus mandshurica var. japonica, Sorbus alnifolia and Magnalia obovata were also present but to a lesser extent. The summits of O-Usu and Ko-Usu were partially covered by rock detritus and shrubs (Ito and Shimizu, 1980; Riviere, 1982).

The $1977-1978$ eruptions severely damaged the vegetation of the atrio in various ways (RIVIERE, 1982). All trees in the vicinity of the craters were blown down by the blasts accompanying each eruption. Direct hits by lithic fragments and pumice which were ejected from the new craters also lashed the trees during major eruptions; the tree trunks remained standing with only a few main branches left and the bark was often removed like sheets of paper. All plants 
were buried by the fallout of thick tephra. The damage, due to ashfall, was sometimes amplified by rainfall which happened at the same time; the ash turned to mortar and stuck to the leaves and branches, crushing tall herbs and trees.

\section{SURFACE EROSION IN THE ATRIO}

Our erosion survey was based on aerial photo interpretation and field examination by repeated visits. For detailed examination of the manner and rate of erosion, erosion pins and painted sediment lines were installed at selected sites.

\subsection{General erosion trend}

The tephra-covered atrio was prone to rapid erosion. Fig. 2 illustrates the main features of geomorphic processes in 1983. Following the upheaval of the U-shaped block, rock fall processes formed a talus on the footslopes of O-Usu, the southern foot of Ogari-yama, and the western foot of Usu Shinzan. Slopes were chiefly sculptured by sheet wash, rilling and gullying. Although not shown in Fig. 2, some mudflows and shallow landslides occurred soon after the accumulation of new tephra (KATSUI et al.,

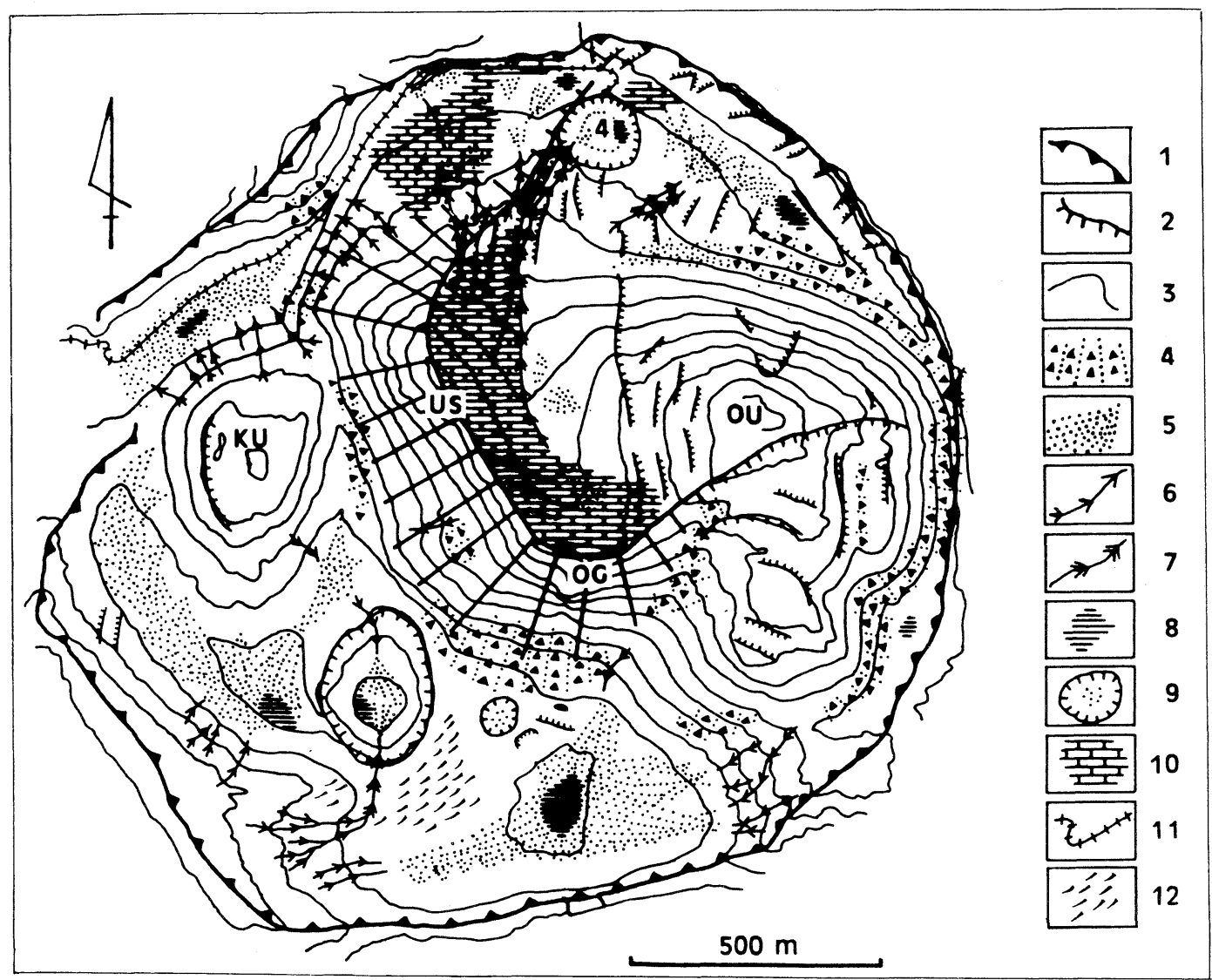

Fig. 2 Geomorphological map of the atrio based on interpretation of aerial photos taken in 1983 (partly modified from CHINEN and RIVIERE, in press)

1: Somma rim; 2: Fault-scarp and flexure including landslide-scarp; 3: Contours for every $25 \mathrm{~m}$ as of 1980; 4: Talus; 5: Alluvial cone and fan; 6: Large gully (top width more than $5 \mathrm{~m}$ ); 7: Large gully cutting into pre-eruption soil; 8: Pond or depression; 9: Crater; 10: Artificial terraces; 11: Road; 12: Area where wind erosion prevailed during dry periods.

OU: O-Usu (731 m); OG: Ogari-yama (668 m); KU: Ko-Usu (550 m); US: Usu Shinzan (662 m)

A comparison with Fig. 1 shows a formation of the new cryptodome (Usu Shinzan - Ogari-yama rise) which vertically displaced c. $180 \mathrm{~m}$ and resulted in tilting of the northeastern atrio surface by $11^{\circ}$. 


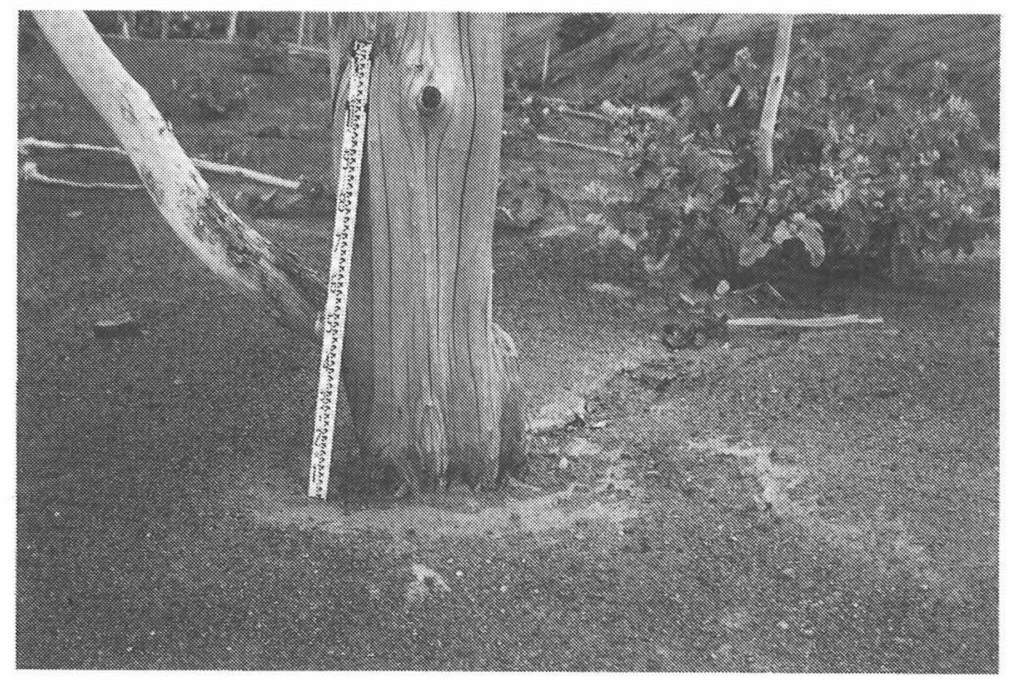

Photo 2 An example of rill initiation (30 August 1986)

Running water stemming from a dead standing tree caused rilling which in turn favored establishment of Polygonum sachalinense on a gentle slope $\left(15^{\circ}\right)$ near the southern somma rim. The staff is $1.2 \mathrm{~m}$ long.

1978; YAmAGishi et al., 1982). However, they had a comparatively minor effect on sediment yield.

Gullying was a prevailing erosion process in the atrio. Parallel rills and gullies have been densely distributed. A number of fault-conditioned gullies were also formed in the northern atrio, in which the largest gully was formed. Most rills initiated on the upper slope and coalesced to form gullies on the middle slope, terminating on the lower slope. Occasionally, gullies had some knick points up to a few meters high at places where plant roots or blocks were exposed. Large gullies reached more than $10 \mathrm{~m}$ wide and $5 \mathrm{~m}$ deep.

Though no quantitative data are available, field observations indicate that rill initiation on slopes was partly governed by rain water running down tree trunks (Photo 2); dead standing trees favored rill initiation. Thus distribution of the dead standing trees might have controlled the spatial rill pattern.

Large gully networks were formed on the Ushaped block (northeastern atrio) and in a catchment which drains into the Ginnuma Crater (Fig. 2). Large gullies of the networks had steep, sometimes vertical sides and were deeply incised. Except for those areas influenced by tilting and base level lowering due to the formation of new craters, very few gullies cut into the pre-eruption soil by 1984 , suggesting a strong resistance of the pre-eruption root mat layer against erosion. Thus the pre-eruption soil was exposed in gullies.

Seasonal variation in the gullying process was of great contrast. Water erosion became predominant when heavy rain fell in the summer. Collapse or free-fall of particles by frost action prevailed in the winter, especially on snow-free steep side-walls. In the snowmelt season, smallscale mudflows and gelifluction-type soil creep occurred owing to the melting of frozen soil. Sediments, therefore, generally resided on gully beds during the period from late autumn to early spring and were discharged during the summer. The sediment discharge often occurred in the form of sediment-laden water runoff and occasionally small-scale debris flow soon after the eruptions.

A number of small-scale mudflows on gully sides as stated above also took place on steep slopes during the snowmelt season. Their average size, including erosional and depositional zones, was $10-20 \mathrm{~m}$ long and $0.1-0.5 \mathrm{~m}$ wide. Such mudflows, showing minor effect on sediment yield, occurred as a result of oversaturation of superficial layers by snowmelting and rainfall. 


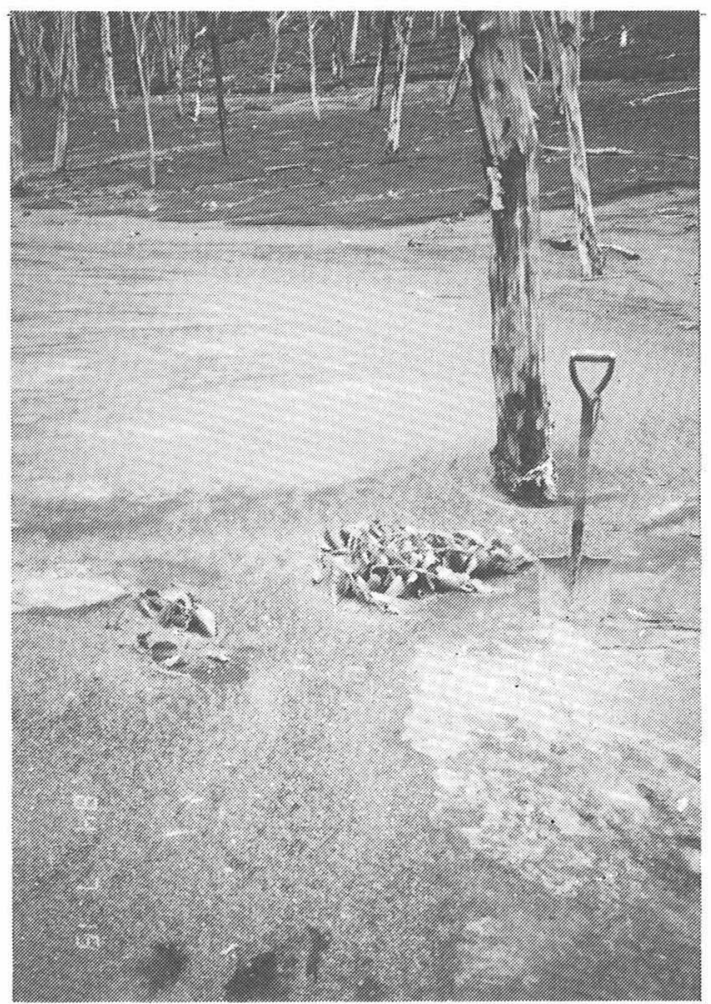

Photo 3 An example of plants damaged by wind erosion near site A (15 July 1984)

Ash was easily transported by wind and accumulated in rills and gullies, thus damaging young herbs which preferentially grew in rills and gullies. Note some rills and gullies buried in this way. Small-scale aeolian landforms such as sand ripples, sand deposits in leeward of fallen trunks, etc. were also observed.
Sediment reworked by rilling and gullying produced alluvial cones and fans on footslopes and atrio floor; lithic fragments as large as 0.5 $\mathrm{m}$ in diameter were also transported by gullying at an initial stage, resulting in a complete destruction of young saplings. Remobilized sediments resided within the atrio except for an event in 1981: sediments of the northern atrio overflowed the somma rim, resulting in formation of an embryo barranco.

Wind erosion, a negative factor for plant reestablishment, was observed on gently sloping areas around Ginnuma Crater in dry periods (Fig. 2, Photo 3); we observed saplings partly buried in ash.

The prevailing erosion process in the atrio changed from slope wash and rilling to gullying over time during 1977-1982 (CHINEN and KADOMURA, 1986). In other words, surface runoff and associated slope wash and rilling frequently occurred and dominated at the initial stage of erosional evolution (YАмАмото and IMAGAWA, 1983; YамAмото, 1984).

\subsection{Measurements of erosion depth}

Utilizing erosion pins, we tried to quantitatively detect erosion depth on the slopes. Steel pins, 4 $\mathrm{mm}$ in diameter, were vertically driven into the ground at different sites, leaving $10-50 \mathrm{~cm}$ of their length above the ground. Each pin was spaced $0.5-2.0 \mathrm{~m}$ from the others. Length of the pins varied according to the depth of the new

Table 2 Ground lowering measured by erosion pins

\begin{tabular}{|c|c|c|c|c|c|c|c|c|c|}
\hline \multirow{3}{*}{ Site } & \multirow{3}{*}{$\begin{array}{c}\text { Slope } \\
\text { angle } \\
\text { deg. }\end{array}$} & \multirow{3}{*}{$\begin{array}{l}\text { Length } \\
\text { of pins } \\
\mathrm{cm}\end{array}$} & \multirow{3}{*}{ Time interval } & \multicolumn{3}{|c|}{ Rill or gully } & \multicolumn{3}{|c|}{ Inter-rill or inter-gully } \\
\hline & & & & \multirow{2}{*}{$\begin{array}{c}\text { Number } \\
\text { of pins }\end{array}$} & \multicolumn{2}{|c|}{$\begin{array}{c}\text { Ground lowering } \\
\mathrm{mm}\end{array}$} & \multirow{2}{*}{$\begin{array}{l}\text { Number } \\
\text { of pins }\end{array}$} & \multicolumn{2}{|c|}{$\begin{array}{l}\text { Ground lowering } \\
\mathrm{mm}\end{array}$} \\
\hline & & & & & mean & s.d. & & mean & s.d. \\
\hline A & 4 & 200 & $06.08 .1983-29.06 .1984$ & 0 & & & 16 & 1.0 & 18.0 \\
\hline B up & 31 & 170 & $06.08 .1983-07.07 .1984$ & 2 & 22.5 & 6.4 & 30 & 3.8 & 13.4 \\
\hline B low & 33,12 & 170 & $06.08 .1983-30.06 .1984$ & 11 & 16.3 & 42.8 & 17 & 5.2 & 20.4 \\
\hline $\mathrm{C}$ & 3 & 170 & $04.08 .1983-30.06 .1984$ & 0 & & & 26 & -80.0 & 52.0 \\
\hline D up & 15 & 150 & $06.08 .1983-06.07 .1984$ & 11 & 12.2 & 33.4 & 21 & 3.3 & 7.1 \\
\hline D low & 10 & 120 & $06.08 .1983-06.07 .1984$ & 7 & 92.9 & 96.3 & 25 & -4.6 & 10.8 \\
\hline $\mathrm{E}$ & 18 & 150 & $15.11 .1982-06.08 .1983$ & 3 & -3.9 & 0.5 & 22 & -0.2 & 1.1 \\
\hline $\mathrm{F}$ & 18 & 150 & $15.11 .1982-06.08 .1983$ & 6 & -1.8 & 2.6 & 8 & 1.0 & 2.3 \\
\hline
\end{tabular}

s.d.: Standard deviation. Erosion at sites $\mathrm{E}$ and $\mathrm{F}$ was measured by a ruler without a washer; the other measurements were made with a washer to form a standard reference level on the surface. Artificial grass sowing was done at site E in 1982. For location of the sites see Fig. 4 . Minus value of ground lowering means deposition. 
tephra (Table 2); the pins were longer than the thickness of the new tephra to minimize the risk of disturbance, physical compaction of the new tephra and frost action. Measurements, accurate to $1 \mathrm{~mm}$, started about one month after the installation of the pins to avoid disturbance induced by the installation itself. Sites A, B, upper

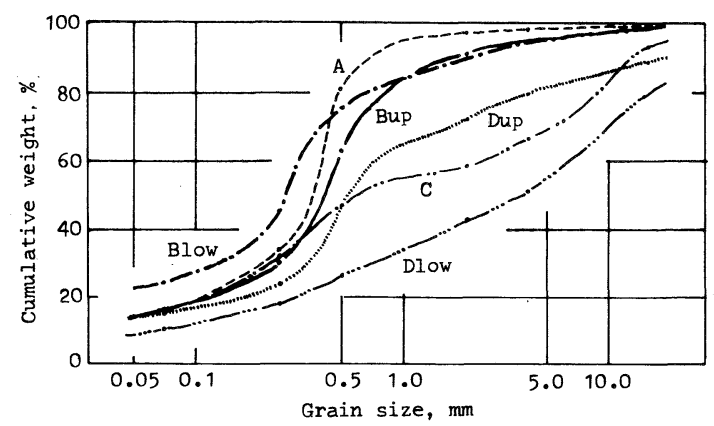

Fig. 3 Grain size distribution of surface layer of the new tephra collected from sites A - D

Two to three samples at each site were analyzed by mechanical sieving. For locations of the sites see Fig. 4. Bup and Blow, for example, mean upperslope and lowerslope of site B, respectively. part of $\mathrm{D}, \mathrm{E}$ and $\mathrm{F}$ are located in erosional areas (Figs. 2 and 4). Sites $A$ and $C$ are on the floor of the southern atrio. Site B is located on the north-facing, inner somma slope, and sites D, $\mathrm{E}$ and $\mathrm{F}$ on the U-shaped block.

Grain size distribution of subsurface new tephra at each site was analyzed to make clear the spatial variation.

The results are presented in Fig. 3 and Table 2.

Fig. 3 indicates that sites A and B, located in the southern atrio, are characterized by abundant well-sorted and fine materials when compared with site $\mathrm{D}$. The significant difference between the group of $\mathrm{A}$ and $\mathrm{B}$, and the group of $\mathrm{C}$ and $D$ reflects secondary modification of composition by erosion, because fine tephra of uniform texture was ejected at the Second Stage eruptions and covered the entire atrio to at least $10 \mathrm{~cm}$ in depth (Fig. 1).

Measurements of the pins seem to reflect the combined effects of rain splash, slope wash, rilling and, to a minor extent, wind erosion. The measurements in the present study showed c. 2 $\mathrm{mm}$ of average ground lowering in inter-rill or

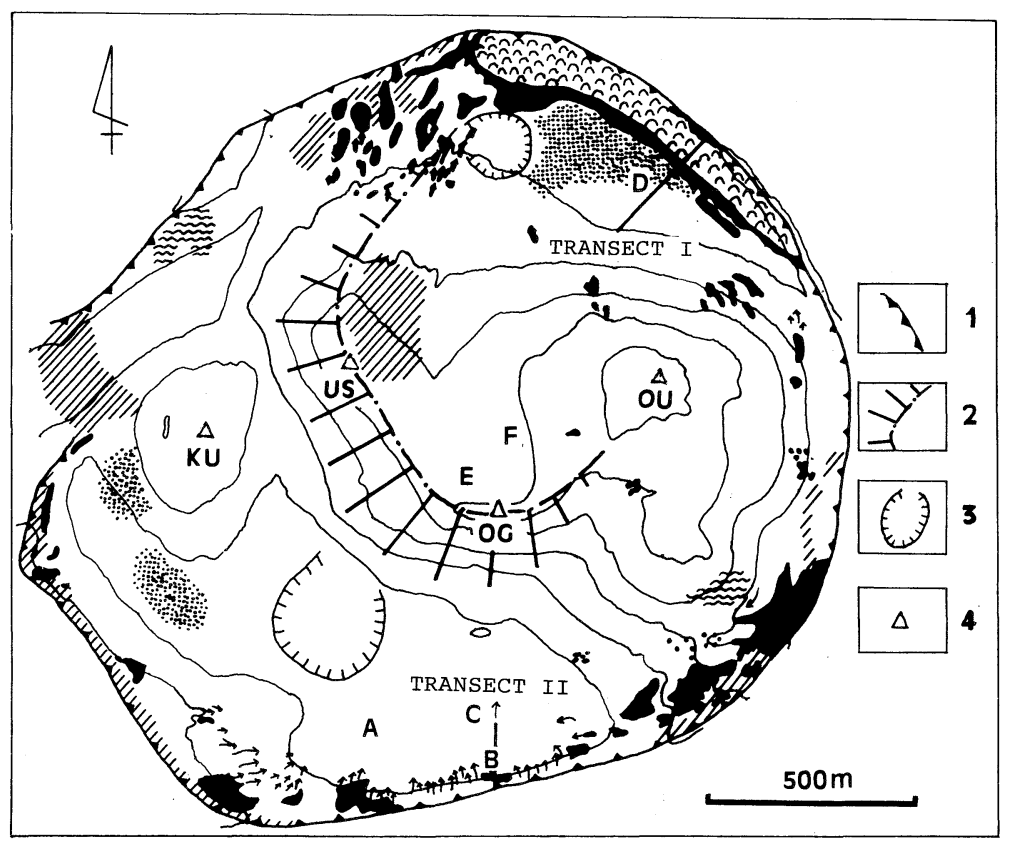

Fig. 4 Plant recovery in the atrio, as of July 1981 (partly modified from RIVIERE, 1982)

1: Somma rim; 2: U-shaped fault-scarp; 3: Crater; 4: Main peak. Contours for every $50 \mathrm{~m}$. Legend for plant cover, see Fig. 5. 


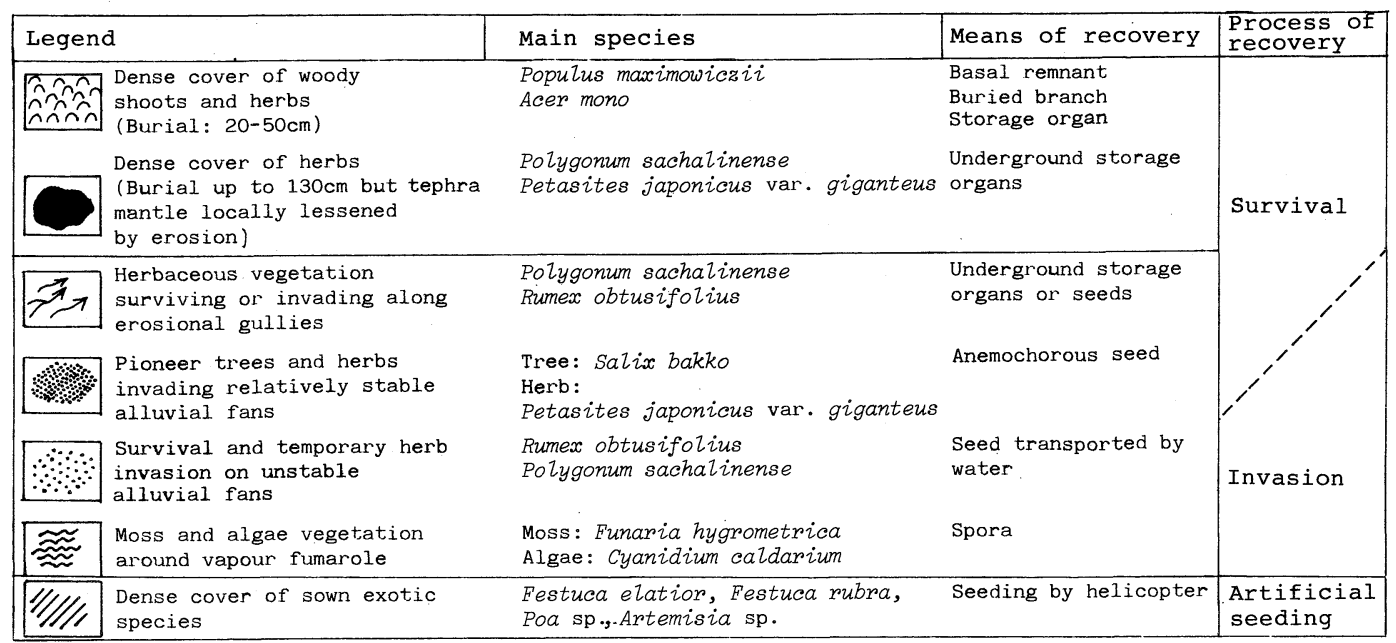

Fig. 5 Legend for plant cover in Figs. 4 and 6

inter-gully areas during the study period except for site $C$ (Table 2). Heavier erosion took place at site $\mathrm{B}$ than at site $\mathrm{D}$. Within the erosional zone of the slope (site B), the lower part was subjected to heavier erosion than the upper part, suggesting that the lower slopes were prone to relatively prolonged severe erosion. The rapid deposition rate at site $\mathrm{C}$ was also verified by field examination of the tephra profile (Fig. 7). Great variability of ground lowering probably resulted from spatial discontinuity of sediment movement on the slopes and in the rills and gullies.

Although no erosion data for the atrio are available for the period soon after the eruptions, data obtained from an adjacent tephra-covered slope, $1 \mathrm{~km}$ away in the northwest direction from the atrio (YАмАмото, 1984), indicate that severe slope wash and rilling occurred during 1978- 1979 and followed by a rapid decline of erosion rate thereafter (CHINEN, 1986). The average value of $2 \mathrm{~mm}$ of ground lowering ob- tained from this study parallels with the decelerating tendency of the erosion rate mentioned above.

\subsection{Monitoring of painted sediment lines}

Movement of surface materials was traced by using painted particles. The particles, originally sampled from the place in situ, ranged in grain size from 0.5 to more than $4 \mathrm{~mm}$. The sites (A, $B$ and $C$ ), at which in total four painted sediment lines $5 \mathrm{~cm}$ wide and $2-4 \mathrm{~m}$ long were established in 1984 , were $5-10 \mathrm{~m}$ away from the measurement sites of the erosion pins. Displacement values were estimated from detailed mapping of the particles.

The results are shown in Table 3 . Visual measurements were exceptionally taken at site $\mathrm{C}$ because of great dispersion of the particles. Although the very short period of observation makes it risky to understand and to estimate the rate of the particles' movement, some spatial var-

Table 3 Displacement of the painted lines

\begin{tabular}{cccccc}
\hline Site & Time interval & \multicolumn{2}{c}{ Displacement, m } & Rainfall & Remarks \\
\hline $\begin{array}{c}\text { A, } 4^{\circ} \\
\text { gentle, smooth }\end{array}$ & $17.05 .1984-23.06 .1984$ & 1 & 4 & 50 & $\begin{array}{l}\text { Most particles showed } \\
\text { upslope movement }\end{array}$ \\
$\begin{array}{c}\text { Bup, } 31^{\circ} \\
\text { rilled slope }\end{array}$ & $26.05 .1984-10.06 .1984$ & 0.1 & 0.5 & 15 & $\begin{array}{l}\text { Downslope movement, } \\
\text { rapid in rills } \\
\text { Blow, } 15^{\circ} \\
\text { gullied slope }\end{array}$ \\
\hline
\end{tabular}


iations can be noted.

Most particles of the line at site A showed upslope movement; particles more than $4 \mathrm{~mm}$ in diameter were also transported upslopeward, indicating severe wind erosion. In contrast, the downslope movement of all particles was traced on slopes of site B. We observed that the particles' movement was more rapid in rills and gullies than in inter-rill and inter-gully areas. Though not represented in Table 3 , site $\mathrm{C}$ (gentle fan of $3^{\circ}$ of slope) showed very rapid movement of particles in water paths, indicating a still active state of fan in 1984. These findings of spatial variation are largely consistent with the results of the measurements of erosion pins described before.

\section{PLANT RECOVERY}

\subsection{Methods}

Early field observations implied that plant recovery responded naturally to the initial damages, but also interacted strongly with posteruption erosion processes. We therefore mapped plant cover and erosional and depositional patterns through aerial photo interpretation and field examination. The aerial photos (approximate scale 1:6000) were taken in July 1981 and October 1983, and then atrio-scale mappings were conducted. Presence of shadows and distortions in surface cover of steep slopes on the photos did not allow a precise mapping; the extent of plant coverage is not precisely comparable between the maps of 1981 and 1983 . Nevertheless, we believe that such inexactitudes do not affect an evaluation and comparison of the maps from viewpoints of general trends of plant recovery.

After the atrio-scale mapping, a transect survey of revegetation, together with slope profile and tephra profile, were conducted to examine spatial variation from the somma rim, closer to less damaged forest, to the central part of the atrio where relatively severe damage took place. Surveying of the transects about $1 \mathrm{~m}$ wide which passed through different vegetation groups was done in June - July 1984.

\subsection{Results}

Plant recovery processes in the atrio were divid- ed into two categories: survival and invasion (disseminule origin) (RIVIERE, 1982). A surviving plant could easily be recognized by digging at the foot and following the rhizomes to the underlying soil. Invaders were differentiated from survivors by their disseminule origin. High plants whose seeds were transported to and germinated in gullies were considered to be invaders.

\subsubsection{Vegetation map of 1981}

Fig. 4 shows plant coverage in 1981 . The cover by surviving woody species was subjected to little change from the initial stage $(1978-1979)$, but the areas covered with herbaceous plants may have expanded for $2-3$ years due to rhizome elongation.

The larger survival was observed on the northeastern somma walls. Woody species, i.e., poplar, Populus maximowiczii, willows, Salix bakko, $S$. sachalinensis, S. integra, and maple, Acer mono, survived by sending new shoots from basal remnants or buried branches. Basal sprouting seemed to be limited to young individuals. No shoots sprouted from the base of large trees.

In contrast, herbaceous plants, i.e., Petasites japonicus var. giganteus, Polygonum sachalinense, Rumex obtusifolius, and Equisetum arvense, thrived through thick deposits probably due to their high re-growth rate of underground organs. Polygonum sachalinense, which perforated up to $1 \mathrm{~m}$ of deposits, displayed more vigorous growth than other herbaceous plants. Although no detailed morphological study of underground organs was performed, the particular adaptation of Polygonum sachalinense may be partly accounted for by the finding that the plant anchored strongly its long rhizomes in many directions.

Plants found growing on gully sides or bottom were sometimes surviving organisms, but, to a greater extent especially at the gully's middle and lower courses, were invaders. In autumn, we observed thousands of highly viable seeds which had been liberated by the surviving species or by the recent invaders present in or around the gully itself, or in distant upward areas, near the gully heads or on the somma rim (Photo 4). In the spring and summer seasons of the following year, those seeds had developed into a dense herb cover.

Apparently inactivated alluvial fans in the 


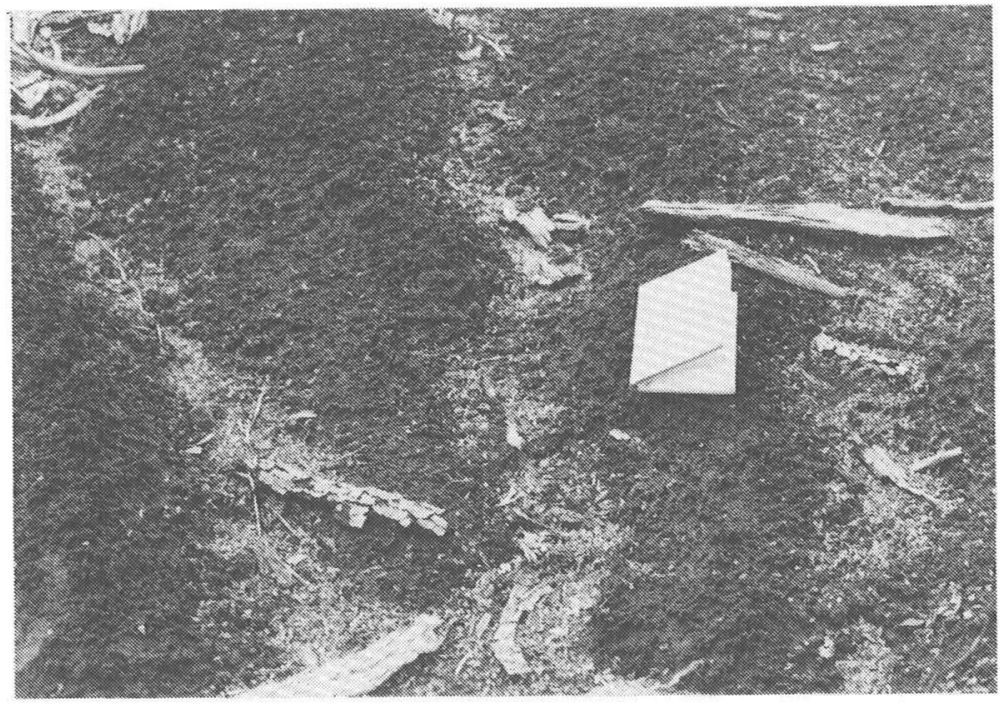

Photo 4 Thousands of seeds liberated by surviving species or recent invaders (6 November 1986)

Note that the seeds, mostly Polygonum sachalinense and Rumex obtusifolius, are localized in rills. Numerous seeds were also observed in gullies.

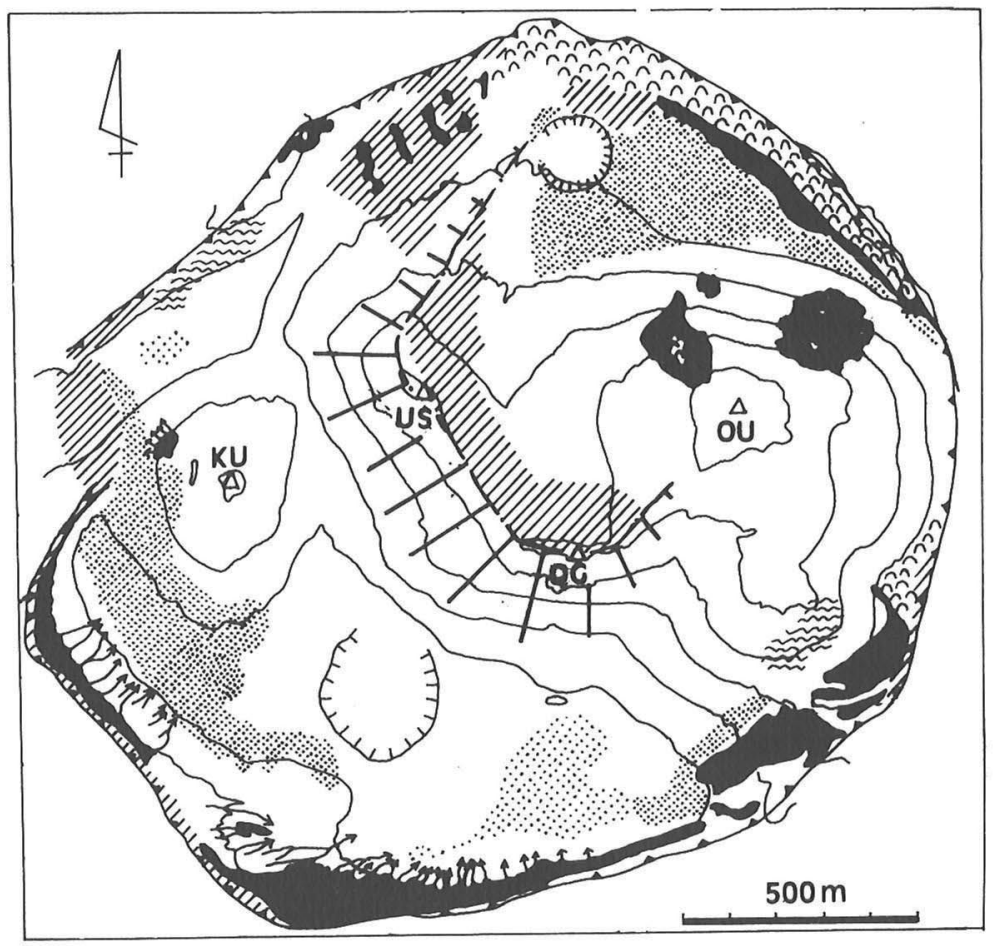

Fig. 6 Plant recovery in the atrio, as of October 1983

Legend for plant cover (see Fig. 5), the same as in Fig. 4. Contours for every $50 \mathrm{~m}$. 
northeastern and western areas of the atrio were the first places to be invaded by pioneer trees. Most saplings belonged to the four genera of $\mathrm{Sa}$ lix, Populus, Betula and Alnus. Herbaceous plants also extensively colonized these alluvial fans. The invading tree seeds came from outside the atrio, but the seeds of herbaceous plants largely originated from surviving species on the somma walls and rim.

The fumarolic zones, called also vapor fumaroles, offered a preferential habitat to colonies of algae and mosses. These were distributed on the northwestern and western somma walls and on the southeastern flank of O-Usu.

\subsubsection{Vegetation map of 1983}

In 1983 (Fig. 6), forest survival occupied the same area, but surviving trees were newly detected on the northern and southern flanks of $\mathrm{O}$ -

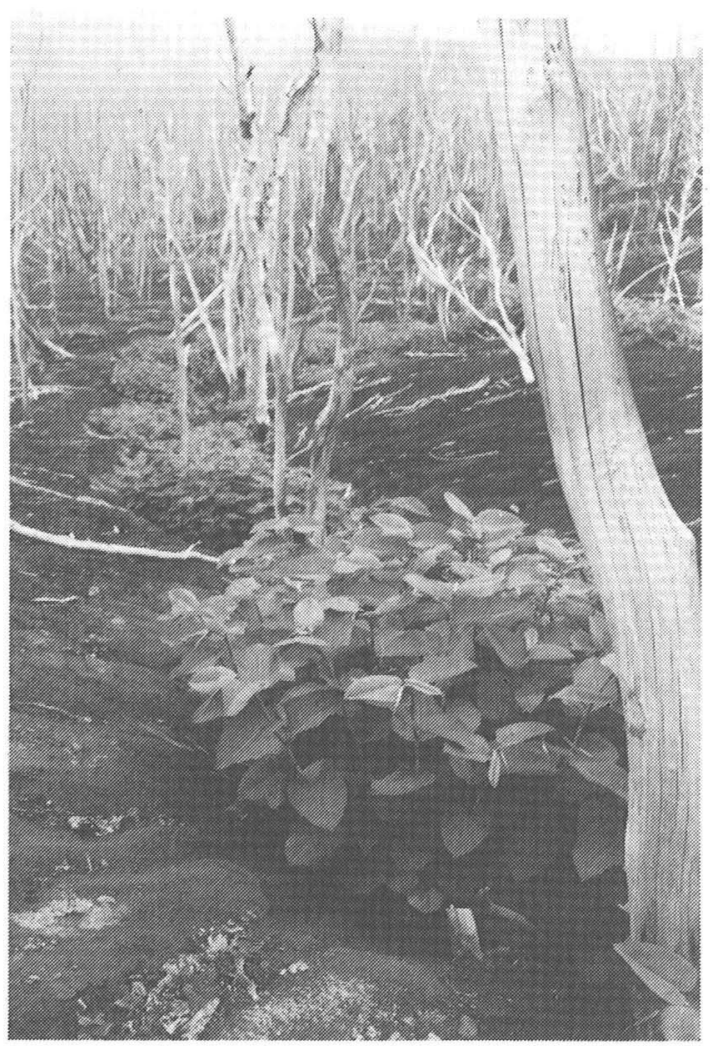

Photo 5 Prosperous regrowth of Polygonum sachalinense in a gully, southern Ginnuma Crater (June 1984)

Gullying which cut the new tephra layer often exposed the old soil surface and favored survival and invasion of plants. Distance from the somma rim is c. $30 \mathrm{~m}$.
Usu. Herbaceous plants which originated from the surviving ones had greatly expanded down the southern somma walls and on the southeastern flank of O-Usu. The expansion, which was partly related to the continuous erosion of the tephra mantle, resulted mainly from rhizome growth but also from seed distribution close to the mother plant (Photo 5).

The northeastern and western alluvial fans bore a large cover of scattered young trees and herbs. Whereas no vegetation had recovered in 1981 on the northwestern and southern alluvial fans, a temporary herb invasion was recorded in June and July 1983. In June 1983, we observed a massive herbaceous cover in some places of the southern fan totally lacking in surface wood debris, especially near the temporary pond. The digging showed that some individuals, deeply anchored, were survivors reappearing at the surface after previous burials by transported materials. Most of the plants, however, were small in size and had their root systems shallowly anchored. These plants were interpreted to be recent invaders. Two herbaceous plants, Rumex obtusifolius and Polygonum sachalinense covered the fan. The origin of the invasion was easy to recognize, for the plants had also established themselves in major rills and gullies running from the somma wall toward the fan. Most seeds had been brought into the depressions by running water in rills and gullies; the two species mentioned above have seeds with a hard coat which is unlikely to be damaged by running water and debris. In autumn 1983, the previously observed vegetation on the south side had totally disappeared. The entire alluvial fan and depression therefore became barren once more; the plants were buried by redeposited ash and pumice. The redeposited materials reached to a depth of $7-14$ $\mathrm{cm}$. The following year (1984), the same June - July greenery phenomena were observed again.

The moss-algae invasion around fumaroles persisted, displacing locally according to appearance and disappearance of fumarolic spots.

No sign of colonization was observed in the very unhospitable habitats, strongly eroded and hot-sulfurous: the lower portion of the western somma wall, the eastern area of Ginnuma Crater where a surface hard crust had formed, and sol- 
fataras between Ko-Usu and Usu Shinzan. The ash-covered gentle hillslopes were still bare in 1984 , but herbaceous plants on the ash were less rare than in 1981. The pioneer herb, Polygonum sachalinense, appeared to be the most successful species to grow here and there on the bare and smooth ash fields. Our field observations indicate that major progress in herbaceous plant invasion on the ash-covered hillslopes occurred around $1983-1984$. In contrast, almost no tree seedlings had invaded yet in the eastern areas of the Ginnuma Crater and on the southern atrio floor in 1983 and 1984 only a few Salix bakko were observed in places protected from abrasive wind.

\subsubsection{Transect survey}

Transect I (Fig. 7) runs through the northeastern atrio, from the somma rim to O-Usu; this line crosses the forest survival area on the gentle somma walls, which is a dominant feature in the northern atrio. The limit of tephra depth for survival of woody species is estimated at about 50 $\mathrm{cm}$ in the northeastern part. In harmony with the spatial pattern of plant recovery (Figs. 4 and 6), three major vegetation groups were observed in the northeastern part of the atrio: a forest survival area on somma slopes, invading trees and herbs on the relatively stable alluvial fan, and a dense herbaceous community between them. On the fan, tephra deposit including airfall and reworked materials was about $100-150 \mathrm{~cm}$ thick.

Of the 36 woody species (including ligneous liana) which were recognized in the forest survival area of the atrio in October 1981, 35 had regenerated naturally and one, Lespedeza bicolor, was probably sown by helicopter after the eruptions. The large majority of woody species sprouted from basal remnants or buried branches; only a few young trees, although severely damaged, developed foliar buds which persisted over the years on aerial remains (e.g., Sorbus commixta). It was noticed that birch trees, dominant in the previous forest, did not show signs of recovery after the damage; only

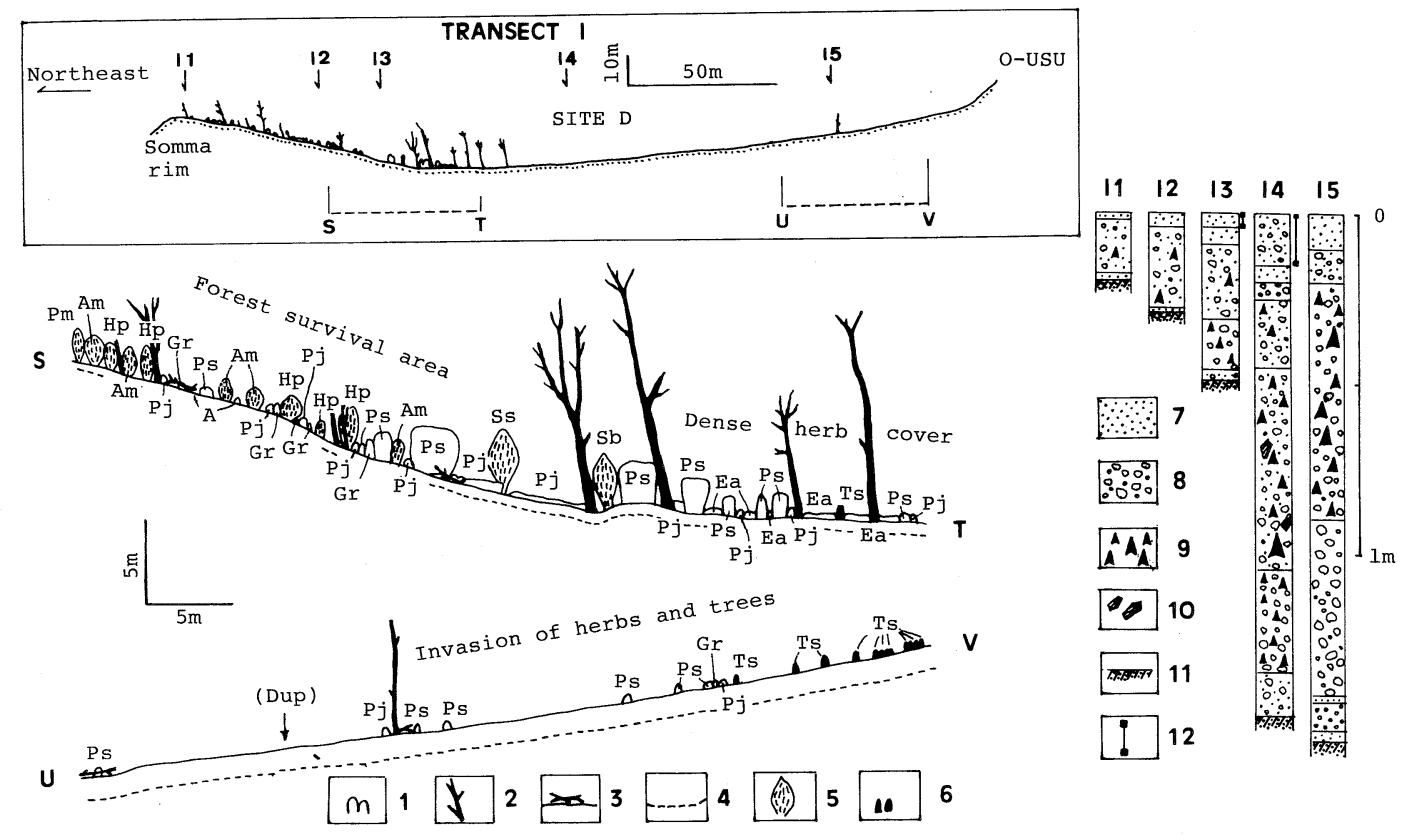

Fig. 7 Slope form, tephra profile and vegetation cover along Transect I

1: Resprouting and invading herbs; A: Artemisia sp.; Ea: Equisetum arvense; Gr: Graminaea sp.; Pj: Petasites japonicus var. giganteus; Ps: Polygonum sachalinense; Ra: Rumex acetosella; Tr: Trifolium repens; 2: Dead standing trees; 3: Fallen trunk or branch; 4: Pre-eruption surface; 5: Resprouted trees; Ae: Aralia elata; Am: Acer mono; Hp: Hydrangea paniculata; Pm: Populus maximowiczii; Sb: Salix bakko; Ss: Salix sachalinensis; 6: Invading tree seedlings (mostly: Salix bakko, Populus maximowiczii, Betula platyphylla var. japonica, Salix sachalinensis, Salix integra, Alnus maximowiczii). 7: Ash; 8: Pumice; 9: Lithic fragment; 10: Wood fragment; 11: Humus; 12: Secondary deposition; ( ): Measurement site of erosion pins.

Location of the transect, see Fig. 4. 


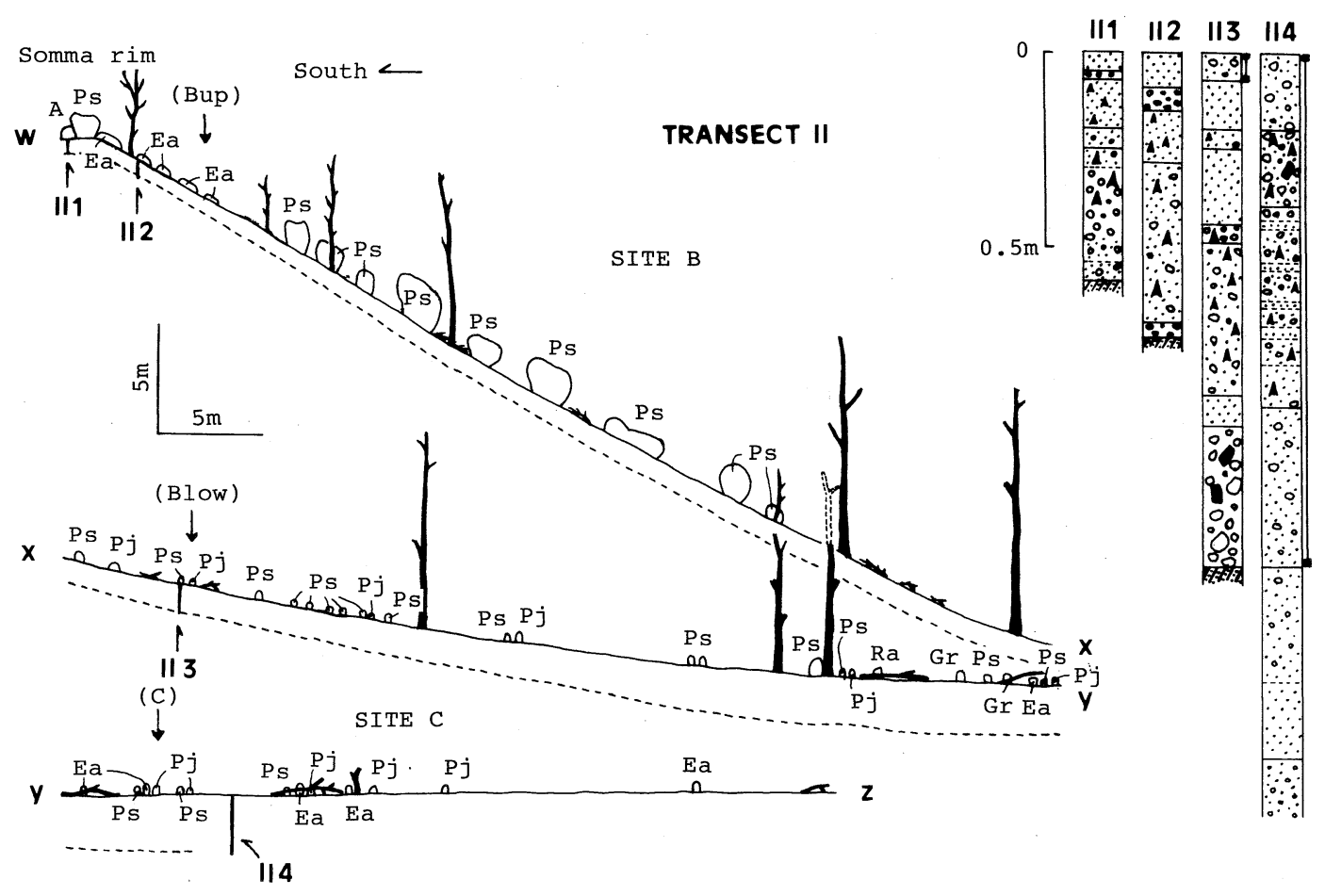

Fig. 8 Slope form, tephra profile and vegetation cover along Transect II Legend the same as in Fig. 7.

one weakly sprouting birch was observed. More than 40 species of herbs and tree ferns were growing among the woody shoots, among which a few species of herb sown by helicopter were included.

Transect II (Fig. 8) traverses the southern somma slope (site B) and the alluvial fan (site C). Transect II shows the dense recovery of Polygonum sachalinense on the upper part of the steep somma walls. $1 \mathrm{~m}$ of depth is considered to be the limit of tephra perforation by the rhizome of the herb. The plant easily recovered in gullies located in southern somma walls because the gullies incised and lessened thick deposits of new tephra. The rapid re-growth of Polygonum sachalinense was a common feature on the somma walls (Fig. 6). Herbaceous plants which recovered on the lower slope were estimated to be invaders. Temporary or very sparse herbaceous invasion was observed on the middle slope of the somma wall.

The dominant herbaceous invaders on alluvial fans were Petasites japonicus var. giganteus,
Polygonum sachalinense, Artemisia sp. and Gramineae sp. All invading trees had very light anemochorous, and easily dispersable seeds. In addition, seedlings appeared to be tolerant to the fluctuation of the soil temperature affecting the open habitats. Because no mother trees were observed within the atrio, the seeds from which young trees originated were assumed to come from the outer somma slopes where the forest had not been as strongly damaged as in the atrio.

\section{DISCUSSION}

In the following paragraphs an attempt will be made to discuss the results of the present study from the viewpoints of spatial and temporal variation of plant recovery and geomorphic processes, and comparisons with studies of other volcanoes.

\subsection{Plant recovery and its limiting factors}

The strategy of survival contributed to a great 
extent to revegetation at Mt. Usu. The sprouting of belowground plant parts was also a widespread process of recovery at Mt. St. Helens, in areas that received tephra of less than $1 \mathrm{~m}$ in thickness (Del Morel, 1983; Franklin et al., 1985). An important fact to be considered with regard to plant survival at Mt. Usu is that the tephra fallout was not of the hot kind and therefore did not destroy the pre-existing soil by burning. It should be noted also that total airfall tephra at Mt. Usu was not deposited in one single event but distributed intermittently over more than a year (August 1977 - October 1978), which probably facilitated the upward penetration of plants.

Dead standing trees played an important role in the initiation of rill erosion (Photo 2). SEGERSTROM (1950) reported the same phenomena observed at Paricutin. In Mt. Usu, the rills, in turn, provided a shelter for liberated seeds and favored establishment of plants. SwAnson et al. (1983) and Collins and DunNe (1988) also noted that revegetation from natural seedlings at $\mathrm{Mt}$. St. Helens has been observed in localized depressions.

We observed that residual downed trees, trunks, and branches interrupted surface water and sediment movement on slopes at the microsite scale. Since most trees were standing immediately after the eruptions at the atrio especially on the somma walls, the effect of retardation of surface erosion was not consequent at Mt. Usu, whereas organic debris embedded in and mixed with the tephra provided protective cover against erosion and contributed to decrease in surface runoff at Mt. St. Helens (Collins et al., 1983; Collins and Dunne, 1986).

An absence of snow cover at the time of eruptions of Mt. Usu induced direct eruptive impacts on the ground surface. In Mt. St. Helens, however, residual snow-pack up to several meters deep protected the plants from thermal and abrasive effects of the blast, and prevented formation of a crust, which facilitated sprouting plants to penetrate new deposits more easily; the deposits which accumulated on the snow-pack were cracked and moistened as snow melted (FrANKLIN et al., 1985). The difference between the two volcanoes shows the importance of the season at which an eruption happens.
Some places were unfavorable for plant recovery. No plant cover was observed on the steepest slopes stricken with utterly damaging erosion processes: the slopes of the three central domes, the walls of the Ginnuma Crater, and the active, large gullies. Fewer plants were also observed on alluvial fans in the northwestern and southern atrio where surface materials were frequently remobilized by surface runoff and wind action; the prolonged remobilization was reflected in both the tephra profile and records of measurement of erosion pins and painted sediment lines. In addition, formation of surface crust and windblown sand limited plant reestablishment particularly in surrounding areas of the Ginnuma Crater.

Rilling and gullying, which were dominant erosion processes during the study period, interacted in various ways. They showed a positive and also a negative effect on plant recovery (CHINEN and Riviere, in press). The favorable effects of gullying dominated on southern somma slopes (Figs. 4 and 5). In the northern atrio, appearance of fault-scarps often aided rilling and gullying which favored plant recolonization through exposure of underlying soil (Photo 6). Incision of gullies which cut through the new tephra was mostly stopped at the surface of the pre-existing soil layer. Plants that recovered from roots and rhizomes protected to some degree the ground surface against erosion. These patterns - positive effects of rilling and gullying on revegetation, and resistance of pre-existing soil layer and recovered plants to downcutting of gullies resemble in many ways those observed at Paricutin (Segerstrom, 1950) and Mt. St. Helens (SwANSON et al., 1983; Franklin et al., 1985; Collins and Dunne, 1986, 1988).

Although some interactions between plant establishment and animal activity were important at some other volcanoes, the effect of animals seemed negligible for the recovery of plants of Mt. Usu; no plant invasion originating from zoochorous seed was observed. Animal tracks, for example, invited hillslope erosion at Katmai (GRIGGS, 1919). Burrowing of pocket gophers and land iguanas on Mt. St. Helens and Galapagos Islands, respectively, helped plant establishment (FrANKLIN et al., 1985; Hendrix, 1981).

Fig. 9 shows the five types of habitat where the 


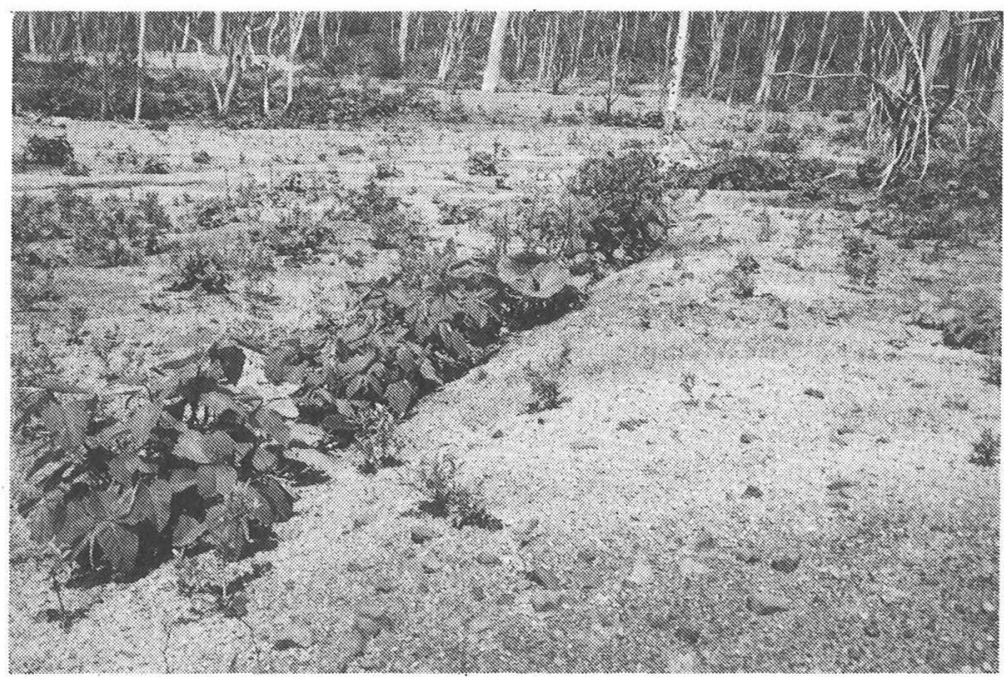

Photo 6 An example of revegetation along a fault-scarplet in the northern atrio of Mt. Usu (June 1985)

The pre-existing soil was exposed along the fault-scarplet, $0.5-1.0 \mathrm{~m}$ high, which favored revegetation from the soil layer itself. Such type of revegetation was often observed in the northern atrio. Gullies did not develop along this fault-scarplet, but gullying frequently occurred along fault traces.
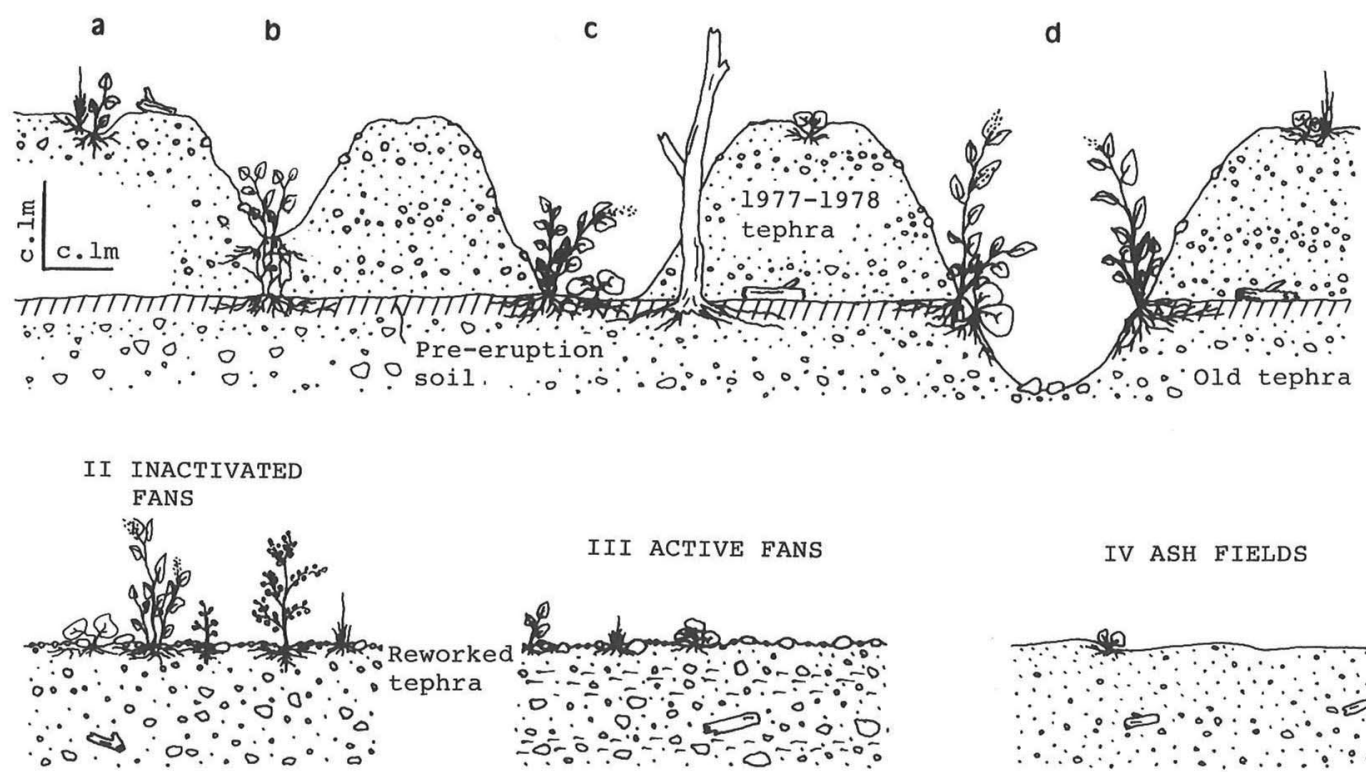

IV ASH FIELDS

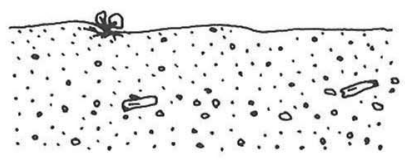

Fig. 9 Schematic diagram showing five typical habitats recognized in the atrio of Mt. Usu

Progressive gully incisions on the slopes with relatively thick tephra (I) were generally stopped at the surface of pre-eruption soil. Gullying, once reached the underlying soil surface, was then dominated by lateral erosion, producing a box-like shape (stage C) in a wider area. Incision by gullying into the old soil and tephra was rarely observed (stage D). For explanation of gully morphology and effects of gullying see the text. Pioneer trees and herbs recovered on inactivated fans more rapidly than on active fans. On ash fields, negative factors such as surface crust, wind erosion and water deficiency retarded plants' reestablishment. 
interaction between plant recovery and geomorphic processes was remarkable. On slopes, rilling and gullying played an important role for revegetation; on alluvial fans, timing of inactivation of geomorphic processes, together with surface materials, controlled plant invasion. Thick ash fields were affected by wind erosion and a formation of surface crust, which limited plant recovery.

\subsection{Temporal variation}

By time trends of plant recolonization, the alluvial fans are divided into three categories. The northeastern fan was already colonized in 1981 by herbaceous plants and numerous, relatively tall $(20-30 \mathrm{~cm})$ tree saplings. The western fan was later covered by fewer herbaceous plants and had much smaller (younger) tree saplings. Trees might have started establishing in $1978-1979$ at the northeastern fan but only around 1981-1982 on the western fan. The northwestern and southern fans were intermittently colonized in 1983, and showed starting signs of permanent establishment of a few herbaceous species in 1984.

The time trend of plant recolonization can therefore be explained by the inactivation of the remobilization of surface materials; field observations and measurements of erosion depth described before indicate that plant recovery took place, largely depending on geomorphic inactivation. Rapid recolonization on the northeastern and western fans seems attributable to the other fact that the fans were covered with reworked white pumices of pebble and granule size that offered a stronger protection for tiny, fragile seedlings against wind and direct sunlight than the smooth and dark ash fields.

Measurements of nutrient contents showed that both the ash and the pumiceous substratum had very low nutritive values (RIVIERE, 1986). Therefore, a lack of nutrients for the new tephra did not appear to be more important for seed plant invasion than geomorphic processes.

These observations and findings emphasize that time-sequential inactivation of geomorphic processes, especially that of gully erosion on slopes and alluvial fans, was a major element controlling plant recovery; in other words, reestablishment of plant communities largely depended on the history of erosion and deposition processes.

In line with the results of the present study, rate of water erosion (slope wash, rilling and gullying) at drainage basin scale rapidly decreased prior to plant recovery at the atrio (CHINEN, 1986). The rapid decline in erosion rate is consistent with other observations at Vulcan (OlLIER and Brown, 1971), Fernandina (HENDRIX, 1981), and Mt. St. Helens (Swanson et al., 1983; CoLLins and DunNe, 1986). This suggests that the decrease in the erosion rate was seldom controlled by plant coverage but by physical factors. Increased infiltration capacity and decreased erodibility of the tephra layer (ҮАмАмото, 1984), exposure of a permeable underlying layer, and the development of a stable rill network (Collins and DunNe, 1986) are considered to be responsible for the deceleration of the erosion rate.

\section{CONCLUSIONS}

Direct hits by blasted rocks and huge quantities of tephra (ash and pumice) deposition, brought about by the $1977-1978$ eruptions of Mt. Usu, generally killed the above-ground parts of plants in the atrio. The following conclusions are drawn from the present study based on aerial photo interpretation and field examination during $1977-1984$.

Plant recovery processes, which were divided into two categories (survival and invasion), strongly interacted with geomorphic processes.

Surviving plants made a great contribution to plant reestablishment. Basal remnants and branches sent new shoots in areas of shallow burial by tephra. Underground storage organs of herbaceous plants easily perforated thicker deposits than the woody plants, and survived on a large area. Plants resprouted in areas of shallow tephra or thick tephra which were secondarily eroded. Thickness of tephra was a primary controlling factor for plant recovery; $1 \mathrm{~m}$ was estimated to be a limit of plant perforation.

Survival and invasion of herbaceous plants in erosional rills and gullies were widespread strategies on the somma wall close to less damaged forest on the outer somma slopes. Rilling and gullying, although destructive (negative) especially soon after the eruptions, showed an impor- 
tant and positive role for revegetation.

Plant reestablishment on alluvial fans was largely dependent on the inactivation of geomorphic processes. Pioneer trees issued from light anemochorous seeds first invaded inactivated fans which were characteristically covered with reworked ash and pumice. Herbaceous plants also invaded the pumiceous substratum in preference to ash fields.

The appearance of fault scarps, which aided rilling and gullying, favored plant rehabilitation through exposure of the preexisting soil layer.

Comparison of the temporal trend of plant recovery with that of geomorphic activity indicates that erosional and depositional activity was a major element controlling the plant recovery; plants recovered after the deceleration of the erosion rate.

Some characteristics of linkages between plant recovery and geomorphic processes at Mt. Usu - a control of tephra thickness, positive effects of erosion processes and inactivation of geomorphic process - are consistent with observations on other volcanoes. At Mt. Usu, geomorphic roles of gullying and new fault scarps for revegetation were remarkably important.

Future research should be encouraged from the points of view of long-term re-monitoring of plant recovery and erosion at $\mathrm{Mt}$. Usu, and evaluation of the recovery with regard to plant succession theory while comparing results with other volcanoes. Determination of seed sources, and their quantitative relationships with invasion processes and establishment on a new tephra field, though not easy, would also be of great interest.

\section{Acknowledgements}

We would like to express our appreciation to Prof. H. KADOMURA (Tokyo Metropolitan University) for his guidance in the course of this study. We are particularly indebted to Profs. S. Higashi, K. ITO, and Y. KatsuI, Associate Prof. H. TAKaHASHI, Dr. M. HARUKI and Mr. H. Үамамото (Hokkaido University), Prof. H. TAGAwa (Kagoshima University), Dr. T. Imagawa (Tokyo Metropolitan University), for their valuable advice. Heartfelt thanks are due to Mr. M. HondA (Sapporo Agriculture Center), Dr. N. NAKAgoshi (Hiroshima University), Dr. M. WatAnABe (National
Museum of Science) and Dr. T. NAITo (Botanical Garden, Tohoku University), for their assistance in plant identification. We owe a great debt to Prof. I. YoKOYAMA (Ciudad Universitaria, Mexico) and the staff of Usu Volcano Observatory for allowing the use of facilities and their kind field assistance. Finally, a profound "merci" is due to Prof. R. VIVIAN and the staff of Laboratoire de la Montagne Alpine (Université de Grenoble I) for their encouragement.

This article arose from the Ph.D. theses: "Plant Recovery Processes on the Summit Caldera of Mount Usu, Hokkaido, Japan" by Anne Riviere and "PostEruption Processes and Sediment Budget of a Small Catchment on Mt. Usu, Japan" by Tamio CHINEN, both of which were submitted to the Graduate School of Environmental Science, Hokkaido University in March 1986.

(Received Mar. 31, 1989)

(Accepted May 1, 1989)

\section{References}

Burke, W. D. (1964): A study of the vegetation of a part of Mt. Tarawera, Rotorua. M. Sc. Thesis, Victoria University.

CHINEN, T. (1986): Surface erosion associated with tephra deposition on Mt. Usu and other volcanoes. Environmental Science, Hokkaido, 9, 137-149.

ChInen, T. (in press): Processus d'érosion dans la caldera du volcan Mont Usu (Japon) après les éruption de 1977-1988. Bulletin de l'Association de Géographes Français.

Chinen, T. and KADOMURA, H. (1984): Gully development and sediment yield in the 4th Crater Catchment on Mt. Usu, Hokkaido, In H. Kadomura (ed.): $A$ Follow-Up Survey of Environmental Changes Caused by the 1977-78 eruptions of Mt. Usu and Related Events. Graduate School of Environmental Science, Hokkaido University, 37-48. (JE)

Chinen, T. and Kadomura, H. (1986): Post-eruption sediment budget of a small catchment on Mt. Usu, Hokkaido. Zeitschrift für Geomorphologie, Suppl.Bd., 60, $217-232$.

CHINEN, T. and A. RIVIERE (in press): Spatio-temporal variation of revegetation with reference to geomorphic processes in the summit atrio of Mt. Usu, Japan, after the $1977-1988$ eruptions. Catena.

Collins, B. D. and DunNe, T. (1986): Erosion of tephra from the 1980 eruption of Mount St. Helens. Geological Society of America Bulletin, 97, 896-905.

Collins, B. D. and DunNe, T. (1988): Effects of forest land management on erosion and revegetation after the eruption of Mount St. Helens. Earth Surface Processes and Landforms, 13, 193-205.

Collins, B. D., Dunne, T. and Lehre, A. K. (1983): Erosion of tephra-covered hillslopes north of Mount St. Helens, Washington: May 1980 - May 1981. Zeitschrift für Geomorphologie, Suppl.-Bd., 46, $103-121$. 
EGGLER, W. A. (1948): Plant communities in the vicinity of the volcano El Paricutin, Mexico, after two and a half years of eruption. Ecology, 29-4, 415-436.

FAULKNER, H. (1974): An allometric growth model for competitive gullies. Zeitschrift für Geomorphologie, Suppl.-Bd., 21, 76-87.

Franklin, J. F., Machahon, J. A., Swanson, F. J. and SEDELL, J. R. (1985): Ecosystem responses to the eruption of Mount St. Helens. National Geographic Research, Spring 1985, 198-216.

GRIGGS, R. F. (1918): The recovery of vegetation at Kodiak. Ohio Journal of Science, 19-1, 1-57.

GrIGGS, R. F. (1919): The beginnings of revegetation in Katmai Valley. Ohio Journal of Science, 19-6, $318-342$.

GRIGGS, R. F. (1933): The colonization of the Katmai ash, a new and inorganic "soil"'. American Journal of Botany, 20, 92-113.

Hendrix, L. B. (1981): Post-eruption succesion on Isla Fernandina, Galápagos. Madrono, 28, 242-254.

HigASHI, S. (1980): Usu eruption and erosion control work. Faculty of Agriculture, Sabo Engineering Laboratory, Hokkaido University, 25p.

IMAGAWA, T. (1984): Hillslope deformation and mass movement on the northeastern somma of Mt. Usu, Hokkaido, associated with the $1977-1982$ volcanism. Geographical Review of Japan, 57(Ser. A), 156-172. (JE)

ITO, K. (1978): Effects of the 1977 eruption of Mt. Usu on the forest vegetation. In: Usu Eruption and Its Impact on Environment, Hokkaido University, 213 - 225. (JE)

ITO, K. and HARUKI, M. (1980): Impact on forest vegetation using the belt transect method. In K. OTA and K. ITO (eds.): '77nen usu-zan funka ni tomonau seitaisen'i no kenkyuu (Studies on ecological succession accompanying the 1977 Usu Eruption), Showa 52-54 nendo Monbusho Kagaku Kenkyuu-hi, Sogo-kenkyu A, Kenkyu-seika Hokoku-shu (Report of Cooperative Research, A), 11-22. (J)

ITO, K. and HARUKI, M. (1984): Revegetation survey of Mt. Usu during six years after the eruption in 1977 - 1978. In H. KADOMURA (ed.): $A$ Follow-Up Survey of Environmental Changes Caused by the 1977-1978 Eruptions of Mt. Usu and Related Events, Graduate School of Environmental Science, Hokkaido University, March 1985, 61-84. (JE)

Iто, K. and ShimizU, M. (1980): Vegetation map of Mt. Usu before the eruptions. In K. OTA and K. ITO (eds.) '77-nen Usuzan Funka ni Tomonau Seitai-sen'i no Kenkyu (Studies on ecological succession accompanying the 1977 Usu Eruption), Showa 52-54 nendo Monbusho Kagaku Kenkyu-hi, Sogo-kenkyu A (Report of Cooperative Research, A), 3-10. (J)

J. W. A. (Japanese Weather Association, Hokkaido Head Office) (1982): Hokkaido no kiko (The climate of Hokkaido). p. 319. (J)

Kadomura, H., Imagawa, T. and Yamamoto, $\mathrm{H}$. (1983): Eruption-induced rapid erosion and mass movements on Usu Volcano, Hokkaido. Zeitschrift für Ge- omorphologie, Suppl.-Bd., 46, 123-142.

Kadomura, H., Yamamoto, H., SuzUKi, R. and SuzUKI, K. (1978): Some aspects of erosional form and processes on tephra-covered hillslopes produced by the 1977 eruption of Usu Volcano, Hokkaido, Japan: August 1977 - early August 1978. In Usu Eruption and Its Impact on Environment, Hokkaido University, 121 - 139. (JE)

Katsui, Y., Oba, Y., OnUma, K., Suzuki, T., Kondo, Y., Watanabe, T., NiIda, K., UdA, T., Hagiwara, S., NAGaO, T., NishiKaWA, J., YAMAMOTO, M., IKEDa, Y., Katagawa, H., Tsuchiya, N., Shirahase, M., Nemoto, S., Yokoyama, S., Soya, T., Fujita, T., INABA, K. and KoIde, K. (1978): Preliminary report of the 1977 eruption of Usu Volcano. Journal of Faculty of Science, Hokkaido University, Ser. IV, 18-3, 385-408.

KINOSHITA, S. and FuKUDA, M. (1982): Relation of snow and ice phenomena to the occurrence of mudflows. In H. KADOMURA (ed.): Usu Volcano Mudflow Disasters and Their Preventive Measures, Monbusho Kagaku Kenkyu-hi Shizen Saigai Tokubetsu-Kenkyu Kenkyu Hokoku-sho, No. A-57-7 (Report of the Grant-in-Aid for Research Project in Natural Disasters, No. A-57-7), 26 46 (J).

Lehre, A. K., Collins, B. D. and Dunne, T. (1983): Post-eruption sediment budget for the North Fork Toutle River Drainage, June 1980 - June 1981. Zeitschrift für Geomorphologie, Suppl.-Bd., 46, 143-163.

DeL Morel, R. (1983): Initial recovery of subalpine vegetation on Mount St. Helens, Washington. American Midland Naturalist, 109, 72-85.

NiIDA, K., SuZUKI, T. and KATSUI, Y. (1982): Sequence of the 1977 eruption of Mt. Usu and the airfall pyroclastic deposits. Bulletin of Volcanological Society of Japan, 27, 97-118. (JE)

NiIdA, K., Katsui, Y., SuzUKi, T. and Kondo, Y. (1980): The $1977-78$ eruption of Usu Volcano. Journal of Faculty of Science, Hokkaido University, Ser. IV, 19-3, 357-394.

OKAMURA, T. (1985): A study of revegetation works for erosion control in active volcanoes. Report of the Geological Survey of Hokkaido, 57, 29-69. (JE)

Ollier, C. D. and Brown, M. J. F. (1971): Erosion of a young volcano in New Guinea. Zeitschrift für Geomorphologie, N. F., 15, 12-28.

Riviere, A. (1982): Invasion and recovery of plants after the 1977-78 eruption of Usu Volcano, Hokkaido, Japan. A preliminary note. Environmental Science, Hokkaido, 5, $197-209$.

Riviere, A. (1984): Wind-borne seed invasion on volcanic desert, the summit caldera of Usu-Zan. A methodological approach. Seed Ecology, 15, 1-29.

Riviere, A. (1986): Properties of the new volcanic substrate of Mt. Usu with regard to natural revegetation. Environmental Science, Hokkaido, 9, 89-112.

RIVIERE, A. and KADOMURA, H. (1984): Impact of erosion control works on the environment, a case study on Usu Volcano. In H. Kadomura (ed.): A FollowUp Survey of Environmental Changes Caused by the 
1977-1978 Eruptions of Mt. Usu and Related Events, Graduate School of Environmental Science, Hokkaido University, March 1984, 117-127.

Segerstrom, K. (1950): Erosion studies at Paricutin, State of Michoacan, Mexico. United States Geological Survey Bulletin, 965-A, p. 164.

SEGERSTROM, K. (1960): Erosion and related phenomena at Paricutin in 1957. United States Geological Survey Bulletin, 1104-A, 1-18.

SEgERSTROM, K. (1961): Deceleration of erosion at Paricutin, Mexico. United States Geological Survey, Professional Paper, 434-D, 225-227.

Segerstrom, K. (1966): Paricutin, 1965 - Aftermath of Eruption. United States Geological Survey, Professional Paper, 550-C, 93-101.

ShimoKawa, E. and TANIGUCHI, Y. (1983): Debris yield from hillside slope of active volcano, In Proceedings of Symposium on Erosion Control in Volcanic Areas, Seattle, July 1982, Technical Memorandum of PWRI (Public Works Research Institute, Japan), No. 1908, 155- 181 .

SHIMOKAWA, E. and Jitousono, T. (1987): Rate of erosion on tephra-covered slopes of volcanoes. Transactions Japanese Geomorphological Union, 8-4, $269-286$.

Swanson, F. J., Collins, B. D., Dunne, T. and WICHERSKI, B. P. (1983): Erosion of tephra from hillslopes near Mt. St. Helens and other volcanoes. In Proceedings of Symposium on Erosion Control in Volcanic Areas, Seatle, July 1982, Technical Memorandum of PWRI, No. 1908, 183-221.

TAKAHATA, S. (1980): Vegetation damage survey by remote sensing. In K. OTA and K. ITo (eds.): '77nen Usu-zan funka ni tomonau seitai-sen'i no kenkyu (Studies on ecological succession accompanying the 1977 Usu eruption), Showa 52-54 nendo Monbusho Kagaku Kenkyu-hi, Sogo-kenkyu A (Report of Cooperative Research, A), 23-28. (J)

UHE, G. Jr. (1971): A contribution to the ecology of vegetation on recent volcanic deposits. Ph.D. Thesis,
University of Auckland, New Zealand. p. 250.

U. V. O. (Usu Volcano Observatory) (1982): Crustal deformations on and around Usu Volcano (Apr. June, 1982). Report of Coordinating Committee for Prediction of Volcanic Eruption, No. 25, 23-27. (J)

WALDRON, H. H. (1967): Debris flow and erosion control problems caused by the ash eruptions of Irazu Volcano, Costa Rica. United States Geological Survey Bulletin, 1241-I, 1-37.

Yamagishi, H., Moriya, I. and Matsui, K. (1982): Deformation, erosion and debris transportation in Usu Volcano since the 1977 eruptions. Earth Science, 36, $307-320(\mathrm{JE})$

YАмамото, H. (1984): Erosion of the 1977-1978 tephra layers on a slope of Usu Volcano, Hokkaido. Transactions Japanese Geomorphological Union, 5, 111 - 124. (JE)

Yамамото, H. and Imagawa, T. (1983): Surface runoff on a slope covered by $1977-1978$ tephra from Usu Volcano. Hydrology, 13, 25-33. (JE)

YAmamoto, H., Kadomura, H., SuzUKi, R. and ImaGAWA, T. (1980): Mudflows from a 1977-1978 tephra-covered watershed on Usu Volcano, Hokkaido, Japan. Transactions Japanese Geomorphological Union, 1, 73-88. (JE)

YANAI, S. (1981): Experimental research on forest formation at volcanic foot. Master's thesis, Graduate School of Agriculture, Hokkaido University. (JE)

Yokoyama, I., Katsui, Y., OBA, Y. and Ehara, S. (1973): Usu-zan - Kazan-chishitsu, funkashi, katsudo no genkyo oyobi bosaitaisaku (Usu-zan, its volcanic geology, history of eruptions, present state of activities and prevention of disasters). Hokkaido Bosai Kaigi (Hokkaido Committee for Disaster Prevention), Sapporo, p. 254 (J)

Yokoyama, I., Yamashita, H., Watanabe, H. and OKADA, H. (1981): Geophysical characteristics of dacite volcanism - The 1977-1978 Eruption of Usu Volcano. Journal of Volcanology and Geothermal Research, 9, 335-358. 


\title{
噴火後の有珠山火口原における植生回復と地形プロセスの関連
}

\author{
知念民雄 ${ }^{11}$, アン・リヴィエール2)
}

1977-1878 年噴火によって荒廃した北海道有珠山の火 口原全域において，1977 年から 1984 年に至るあいだの 自然の植生回復と地形プロセス（侵食扣よび堆積プロセ ス）との関連を調查した。調査方法は，おもに野外での 観察・観測と航空写真判読によった。

植生回復プロセス——残存 (survival) と種子散布によ る侵入 (invasion)——と地形プロセスとの関連はダイナ ミックな様相を呈した。残存は植生回復に大さく貢献し た。樹木の親株と埋没落枝からの萠芽は新期テフラに浅 く覆われた（約 $50 \mathrm{~cm}$ 以下の層厚）区域でしばしば観察 された。数多くの草本植物の地下茎からの回復一一樹木 に比較して容易に厚いテフラ層（約 $1 \mathrm{~m}$ の層厚）を貫い た一ーは広範囲にわたった。テフラに厚く覆われたが, 2 次的に開析された斜面に括いては,リルやガリーに沿 ら草本植物の残存と侵入が一般的に認められた。軽い風 散布種子起源の先駆木本植物は, はじめに火山灰と軽石 に特徵的に覆われ，かつ地形プロセスの鎮静化した扇状
地に侵入した。草本植物の侵入も, 同様に火山灰地より 軽石質の区域に優勢であった。リル拉よびガリ一侵食 は, 植生回復に物理的被害を括よぼす反面, 有機物や種 子を外輪山内壁から斜面下部として火口原へと運搬す ると同時に，旧土壌を露出するという重要な役割を演じ た。

斜面と扇状地に拈ける先駆木本括よび草本植物の定着 の経時変化は地形プロセスの不活発化に大きく左右され た。表面侵食速度は顕著な植被回復の開始以前に急減し た。このことは，実際の植被回復が加速化した侵食を和 らげるのに大きな役割を果たさなかったことを示してい る。むしろ, 地形プロセスの不活発化が植生回復を規定 したと言える。

以上のことは, 植生回復が基本的には噴火の直接的被 害一とくに植生の破壞程度とテフラ層厚一と噴火後 の地形プロセスとその推移に大きく依存することを示し ている。

1）グルノーブル第一大学アルプス地理研究所アルプス山地研究室 モーリス・ジニュー通り，グルノーブル 38031 , フランス

2) 34 , ルノワール通り，ル・マン 72000 , フランス 